\title{
The Prerogative and Environmental Control of London Building in the Early Seventeenth Century: The Lost Opportunity
}

\author{
Thomas G. Barnes*
}

\begin{abstract}
"What experience and history teach is this-that people and governments never have learned anything from history or or acted on principles deducted from it." Undaunted by Hegel's pessimism, Professor Barnes demonstrates that our current concern for the environment is not as new as we might suppose. The most considerable, continuous, and best documented experiment in environmental control in the Common Law tradition was conducted before the middle of the seventeenth century. An almost accidental circumstance determined that this experiment would become a lost opportunity.
\end{abstract}

Now if great Cities are naturally apt to remove their Seats, I ask which way? I say, in the case of London, it must be Westward, because the Windes blowing near ... [three-fourths] of the year from the West, the dwellings of the West end are so much the more free from the fumes, steams, and stinks of the whole Easterly Pyle; which where Seacoal is burnt is a great matter. Now if [it] follow from hence, that the Pallaces of the greatest men will remove Westward, it will also naturally follow, that the dwellings of others who depend upon them will creep after them. This we see in London, where the Noblemens ancient houses are now become Halls for Companies, or turned into Tenements, and all the Pallaces are gotten Westward; Insomuch, as I do not doubt but that five hundred years hence, the King's Pallace will be near Chelsey, and the old building of Whitehall converted to uses more answerable to their quality, .... that the next Pallace will be built [away] from the whole present contignation of houses at such a distance as the old Pallace of Westminster was from the City of

* Professor of History, University of California, Berkeley; Project Director, American Bar Foundation Project in Legal History. A.B. 1952, Harvard; D. Phil. 1955, Oxford. The author used original manuscripts as his source naterial. Citations are to catalog numbers used by the libraries wherein the manuscripts are located. 
London, when the Archers began to bend their bowes just without Ludgate, and when all the space between the Thames, Fleet-street, and Holborn was as Finsbury-Fields are now. ${ }^{1}$

Sir William Petty (1623-1687) was an astute observer, an early econometrician and statistician, and his prediction as to London's growth from the vantage point of 1662 has a modern ring to it. The prediction proved less than prophetic insofar as London-Westminster grew in all directions in the next three hundred years, to become a dense metropolitan area containing over eight million people concentrated within a ten mile radius of the palace at Whitehall. ${ }^{2}$ But as an essay im conventional wisdom it compares favorably with current studies of urbanologists. One such inodern urbanologist, Edward C. Banfield, details the outward thrust of the population of the inner-city under three "imperatives" which are also implicit in Petty's consideration: rate of population growth; technology of transportation; and distribution of income. ${ }^{3}$ Most arresting is Petty's explicit reference to the effect of adverse environmental conditions on the type and direction of urban growth. Long before the so-called Industrial Revolution of the late-eighteenth and nineteenth centuries, coal fires made London increasimgly unattractive, and by contemporary environmental standards uninhabitable. London's consumption of coal increased enormously over the seventeenth century. The production of English coal rose from 210,000 tons im 1560 to $2,982,000$ tons in 1690 , with the largest growth between 1600 and 1660, the largest inarket for which was London and the Thames Valley as a whole." Indeed, an early attempt at air pollution control was the royal patent of invention and monopoly, with supporting proclamation, extended to one Captain Thorness Francke in 1633-1634 for a funnel lood and smokestack which ostensibly reduced by half the smoke emitted in the boiling fires used by brewers, dyers, soapmakers, and saltnakers, to "the lessening of the great annoyance of Sinoke, which is so much obnoxious to our Citty of London, and to all other Citties and Towns corporate."5 In the 1630's a Westminister brewer was prosecuted by the Attorney. General in Exchequer for nuisance in brewing with a coal furnace to the annoyance of the royal palace at Whitehall and the Archbishop of Canterbury's palace across the Thames at Lambeth. ${ }^{8}$ Although faced

1. W. Petty, A Treatise of TAXES AND Contributions 23-24 (1662).

2. This is based on the Census of 1961 for the London Metropolitan Area.

3. E. Banfield, The Unheaventy CtTy: The Nature and Future of Our URBAN CRISIS 23-44 (1968).

4. C. WIISON, ENGLAND'S APPRENTICESHIP, 1603-1763, at 80-82 (1965).

5. 8 RYMER'S FOEDERA (IV), at 81 (1742).

6. Petition of Michael Arnold, Feb. 24, 1641, House of Lords Record Office, Main Papers [hereinafter cited as FLRO Main Papers] (18-26 Feb. 1640/1) ff.195-96. 
with the traditional problems of bad pavements and blocked passageways, the inhabitants of the royal palace were particularly concerned with annoyances "noysome or infectious to the aire" caused by dung and garbage in buildings and streets and by industrial smoke. This concern, shared by all Londoners, moved the King and Council to issue special commissions in 1627 and 1627 to royal and civic officials authorizing the investigation of annoyances and the binding over of the perpetrators to the Privy Council or the Court of Star Chamber. ${ }^{7}$ Such attempts to deal with air pollution were not very successful. They were directed at the symptom rather than the real problem: over-population in and around London. The subsequent attempt by Elizabeth I, James I and Charles I to control building by government action constituted recognition of the root problem. This unique and ephemeral experiment was a remarkable example of governmental perspicacity.

The past always serves as a useful contrast to the present, and an essay in history can, at the least, be justified as a corrective to over present-mindedness in dealing with present concerns. This function is perhaps most valuable when the present concern appears to be very recent in origin and very urgent. The phenomenon of urgency is a constant in the historian's professional experience, and though he never becomes inured to it, he is unremitting in his suggestion that urgency be put in perspective. However, this essay in history goes a step furtler. It atteinpts analysis of the most considerable, continuous, and best documented experiment in environmental control in the Common Law tradition before the middle years of the nimeteenth century. The experiment was made at a time when the initiative for the advancement of the commonweal was still in the liands of a strong executive. An almost accidental circumstance determmed that the experiment in environmental control would not make a permanent inpression on the Common Law, and that it would, with the strong executive that had undertaken it, disappear in the English Revolution of the mid-seventeenth century. As a consequence, the law of environmental control lias had to be fashioned largely from a contemporary legislative base reflecting very recent (and increasingly urgent) concerns.

The development of substantive and adjective environmental law will be uneven because of the lack of practical experience with the possibilities of reasonable and viable doctrines in law for environmental control. For legislatures, the judiciary, the profession, and the interested parties, the evolution of a viable law of environmental control will be costly in time, energy, and money. We will witness false hopes and false starts, discarded procedures, the brake of excessive cau-

7. 7 RYMER'S FoederA (IV), at 96-98 (1742); 8 id. (II), at 135-37. 
tiousness, the wasted acceleration of excessive enthusiasm and unclear legal definitions of "the public interest," of private interests, of the environment itself. At best the law of environmental control will be fashioned by extension of analogous doctrines in the law mixed with innovative legislation. But for the lost opportunity of the early seventeenth century, it might have been otherwise. From this early experiment, had it survived, we might have derived a solid procedural foundation, some lines of doctrinal development, and even a modicum of substantive rules upon which to build today's environmental law.

\section{I}

THE GROWTH OF LONDON AND BULDING DEVELOPMENT, 1590-1640

In 1590 "metropolitan" London consisted of two distinct cities on the left bank of the Thames-London and Westminister, respectively -and a modest conglomeration of houses on the right bank in the borough of Southwark connected to London by the only bridge over the river in the area, London Bridge, which with its shops and dwellings was virtually an $u r b s$ in itself. The city of London extended some distance beyond the old city wall, which ringed the commercial heart of England on the east, north, and west, the Thames serving as its noat to the south. From the western limit of London proper, at Temple Bar, to the palace of Westminster, a mile of roadway, consisting of the Strand and Whitehall, connected the commercial and political capitals of England. This area constituted the West End, which is of particular importance in this Article. The royal residence was in the palace of Whitehall, just up the road froin the palace of Westminster, which housed the administration, the Common Law courts, Chancery, Star Chamber, Wards and Liveries, and Parliament. Along this mile of roadway, between it and the Thames, was a row of great houses. These houses, of recent construction in 1590 , were the town seats of the Tudor aristocracy. To the north of the roadway, there stretched gardens, orchards, and fields: Lincoln's Inn Fields, Covent Garden, St. Clement's Fields, Long Acre, and St. Giles Fields. These rural out-parishes were already crowded by 1590 with immigrants from the counties of England and Wales and even some from continental Europe and Ireland.

Between 1500 and 1700 the metropolis' population grew phenomenally: from about 50,000 in 1500 to about 250,000 in 1600 and to 530,000 in 1689 . In terms of its relative populousness to the rest of England, London's population was neghibible in 1500, about five percent of the total population in 1600 , and about ten percent of the total in 1700. Another way to put it is that while the total 
population of England and Wales increased by about 40 percent between 1500 and 1600, London's population increased by 500 percent. It doubled again between 1600 and 1700 , while the national population rose by about 30 percent. $^{8}$ The sharpness of the growth during the period with which this Article is principally concerned is perhaps most clearly expressed in the consumption of food stuffs. In 1587-88, 209,700 quarters of grain were imported into London; in $1638,950,000$ quarters. $^{9}$

The newcomers first filled the city of London within the walls, then poured over into the areas just beyond the walls, and finally into the rural out-parishes to the west and northwest of London. Existing dwellings with a single family took in tenants, called "inmates" or "undersitters," not part of the family or servants to the family. The next step was to partition dwellings into inultiple units, a process called "dividing tenements." When the dwellings were filled to capacity, they were cellared and also built higher and further over the street in the cheapest possible manner. Stables, sheds, coachhouses, shops, cookhouses, and every other kind of outbuilding were either converted to dwellings or demolished and replaced by rickety new structures. Some enterprising developers built earth banks upon which they erected sheds to make maximum use of ground. The final stage of development came with new, low-grade, high-built construction on new foundations, in what had once been orchards, gardens, and fields.

The shrewd developer could inake enormous profits. The best documented case is that of John Moore, Esq., one of the four Clerks of the Signet, a writing officer under the two Secretaries of State, a responsible official charged with conducting formal correspondence and the preparation of documents for the Privy Seal. The office was not particularly lucrative: the historian of Charles I's bureaucracy estimates that the three junior clerks each had a minimum annual incoine of between $£ 200$ and $\$ 300$ from pension and ancillary office, diet, gratuities, and fees. ${ }^{30}$ Assuming that this was the value of the office to Moore, he doubled his income by his teneinent investments in and near what had once been an orchard lying between Covent Garden and the old parish church of St. Martin's-in-the-Fields. About

8. Population estimates are hazardous until Gregory King's 1689 survey-hence the seeming exactness of the 1689 figure. See C. WIIson, supra note 4, at 13, 45-47, 229; Joues \& Judges, London Population in the Late Seventeenth Century, 6 EcoN. Hist. REv. 45 (1935).

9. Fisher, The Development of the London Food Market, 1540-1640, in 1 Essays IN ECONOMIC HISTORY 138 (E.M. Carus-Wilson ed. 1966). The quartcr was eight bushels.

10. G.E. Aylmer, The Knng's Servants: The Civil Service of Charles I, at $204(1 \xi \leqslant 1)$. 
1615 he bought the orchard in St. Martin's parish, which he claimed had already become "unprofitable, the trees beinge infruitfull by the buyldings then lately erected round about the sayd orchard."11 Shortly after purchasing the ground, he built 17 coachhouses and 13 stables of timber, which he did not convert to dwellings but retained for their avowed purposes. The coachhouses provided an annual rent of $£ 60$, the stables, $£ 34$. Part of the stables were built on an old dividing wall as foundation. He also constructed seven dwellings, two of which were in part on old foundations; the cellars and first story were of brick, the rest of timber. These houses brought him $\$ 110$ per annum. About 1629 or 1630 , he built near the orchard another five, all-brick dwellings on the site of workshops, coalhouses, and other backbuildings which he demolished. Two of these dwellings were in part on old foundations and the rest on the ground of the demolished backbuildings. This added another $£ 54$ to his annual income. Thus Moore's investment was worth $£ 258$ in annual rent. What this represented in net profit is not easy to determine. Moore claimed that he suffered a loss of $£ 3500$ when 33 of the 42 structures were torn down on decree of Star Chamber in $1634,{ }^{12}$ but this was probably an exaggerated sum and perhaps included a calculation of loss of future rent above and beyond the actual cost of construction. ${ }^{13}$ Obviously, though, Moore was not poor. Within a few months of the decree in Star Clianber lie paid bulk of the $£ 1000$ fine imposed on him for contravention of the building prohibition, partly in cash and partly by levy on his and his surety's goods. ${ }^{14}$

Moore's development was in the West End. This area apparently attracted a larger proportion of new population than any other in the metropolis-“apparently," because our knowledge of London demography in the seventeenth century is still very rudimentary. Undoubtedly the prominence of the West End in the records of the government's attempt under James I (1603-1625) and Cliarles I (1625-1649) to restrict and control building owes a great deal to the fact that it was in the vicinity of the royal palace at Whitehall, the queen's palace, the great houses of the nobility, the more modest town houses of officialdom, and the offices of government. Population growth there was not only more apparent than in already crowded London, it was also more almoying to king, Council, and the courts. However, the at-

11. Bodleian Library, Oxford [hereinafter cited as Bodleian], Bankes MSS. 18/35, examination and confession of John Moore before the Attorney-General, Jan. 22, 1634.

12. See text accompanying notes 76-78 infra.

13. Berkshire Record Office, Trumbull Additional MS. 37.

14. Public Record Office, London, E.401/2454, Squibb, Pas. 10 Chas. I [Public Record Office is hereinafter cited as PRO]. 
tempt to control building in London from 1590 to 1640 included the entire metropolitan area as well as London itself. The Elizabethan proclamations ${ }^{15}$ encompassed an area three miles from the gates of London. The later proclamations of James $\mathrm{I}^{16}$ encompassed an area two miles beyond the gates of London. The first proclamation of Clarles $I^{17}$ extended to two miles beyond the gates of London and the city of Westminister. Charles' last proclamation ${ }^{18}$ extended this to three miles. $^{19}$ The 95 prosecutions between 1590 and 1602 for building in contravention of Elizabeth's first proclamation were dispersed throughout the entire area. ${ }^{20}$ Almost half were from the city of London. Only eleven were from the West End. This was, lowever, rather early in the period. It is probably safe to surmise that if we had comparable evidence for the 1630's, there would be a considerably higher proportion of West End prosecutions, most likely at the expense of London prosecutions.

It is a sad commentary on the evidence that only a partial and tentative identification of the builders and developers is possible. The identification depends first of all on the area considered. In the case of London proper and its close-in suburbs, and espeeially to the east, the evidence suggests that the tenements were erected mostly by small tradesmen and substantial artisans. ${ }^{21}$ Two trades, bricklayer and carpenter, were the most common violators in London and its suburbs, which is no surprise considering the essential nature of their skills to building. The prosecutions included three suburban gardeners, apparently men who found the conversion of their market-gardens to dwelling space more profitable than gardening. In London proper, a sizable group of

15. See text accompanying notes $34-44$ infra.

16. See text accompanying notes 45-57 infra.

17. See text accompanying note 59 infra.

18. See text accompanying note 60 infra.

19. The areas covered by the various proclamations are represented on the map in the Appendix to this Article.

20. PRO, E.159/423, Tr.44 Eliz., rot.95, id. Mich. 44-45 Eliz., rot.246, estreats of recognizances from Star Chamber. The areas represented were:

London

Suburbs to the east of London

Suburbs to the north of London

Suburbs to the west of London (West End)

Westminster

Southwark \& south of Thames

Unknown

Total

21. That is, tailor, cutler, loriner (maker of small iron ware), clothworker, draper, butcher, skinner, turner (wood lathe worker), linenweaver, cordwainer (leather worker), mariner, riverboatman, chandler, grocer, vintner, ironmonger, baker, pewterer, innholder, blacksmith, shipwright, feltmaker, mason, bricklayer, and carpenter. Id. Tr.44 Eliz. rot. 95, id. Mich. 44-45 Eliz., rot.246. 
those prosecuted between 1590 and 1602 were from the upper echelon of civic society: eight citizen-livery company men and two other merchants. The only gentlemen prosecuted-and they were merely gentlemen, not esquires or knights-were four from Westminster and the West End, and they raise the suspicion that they might have been lower-level officials. It is not surprising, since there were so many breweries in the West End, that two brewers were prosecuted. Ten defendants defy categorization beyond their given social rank, yeoman; the four London yeomen and five close-in suburban yeomen could be described as "substantial freeholder farmers" only by too high a leap of the imagination and had best be considered as either recent urban immigrants from the countryside or else small urban property holders perhaps in superior service to an official or gentleman. One Islington yeoman who divided his tenement, imstalling another yeoman in it, might well have been a farmer.

Even at this early date the social status of the West End developers was emerging: gentlemen, a few brewers, and a very few artisans and shopkeepers. By the 1630's, the majority of West End developers were very substantial persons. John Moore, Esq., Clerk of the Signet, already mentioned, might be taken as the norm, or John Trenchard, Esq., who coinbined with a carpenter and another in building around Covent Garden, or William Price, Esq., groom of the King's Privy Chamber, who converted the old Antelope Inn in Holborn and its outlying buildings into dwellings. ${ }^{22}$ Two of the biggest developers were noblemen. Jolin Holles, first Earl of Clare, was a major builder in Holborn around the Inns of Court, for which he was prosecuted in Star Chamber in 1635 and forced to suffer demolition of some of his structures. His heir, who succeeded in 1637, made his peace with the Privy Council and the building commissioners by voluntarily undertaking to build better houses for fewer tenants of better social quality. His developments in Holborn, Reindeer Yard, and in St. Clement's Fields brought $£ 2000$ in annual rentals and some $£ 800$ annually in fines (premiums for leases) by $1648 .^{23}$

The greatest developer of all maintained a family tradition for the business and handed it on to his successors in a dynasty which left an indelible stamp on the West End in Russell Square, Bedford Square, Tavistock Place, and Woburn Square and Place. Francis Russell, fourth Earl of Bedford, who succeeded to the title in 1627, was land-

22. PRO, P.C. $2 / 48$, at $21,229,441$; id. P.C.2/49, at $44-45,79-80,277$; id. P.C. $2 / 50$, at 651 .

23. Folger Library, Washington, D.C. [hereinafter cited as Folger], MS. V.a.278; Attorney General v. Earl of Clare, Mich. 11 Chas. I; PRO, P.C.2/49, at 194-95; L. StONE, THE CRISIS OF THE ARISTOCRACY, 1558-1641, at 361 (1965). 
lord of a very large tract of the ground in the West End. He was a principal builder himself and a proinoter of building by his tenants. He was not prosecuted in Star Chamber in the 1630's for these activities, but he was hard pressed by the building commissioners and the Privy Council for such atrocities as building up the street between the Strand and Covent Garden so heavily that it was hazardous to passage. Professor Stone estimates that by 1660 the fifth Earl of Bedford drew well over £2000 annually froin his Covent Garden and Long Acre properties. $^{24}$ He had agreed with the King to construct a high class and seemly development and, on these grounds, received a patent for development that became a cover for some very unseemly development by his tenants and subdevelopers, men such as John Trenchard inentioned above. ${ }^{25}$

\section{II}

THE ATTEMPT TO CONTROL LONDON BUILDING, 1590-1640

\section{A. Motivation}

There is no evidence that the governmental attempt to restrict building in the metropolis and, later, to establish standards of materials and workmanship for new construction was in response to any general public pressure. Few of the ambitious programs of late Tudor and early Stuart "strict and strait governance" grew from informed public opinion or public pressure, though often such programs were in the public interest and enjoyed a modicum of popular support. At its best, the Tudor-Stuart inonarchy, absolutist though it was in intent-though by force of political circumstances it fell far short of absolutist practice-had an enlightened sense of the "commonweal." This sense and its derivative concern were the original motivation for building control.

The concern was very real. All of the royal proclamations directed at restricting building stressed the dangers of infectious plague in overcrowded urban conditions. What was a hively apprehension in the first proclamations in 1580 and 1602 became a terrible reality in 1603,1625 , and 1636 when virulent outbreaks of the plague struck the country, falling with exceptional mortality on the metropolis. Though contemporary medicine had no notion of the cause of the disease, it was in its most virulent form highly commumicable and it demanded slight credulity to lead to the conclusion that city conditions spawned plague. To plague was added fire as the great fear, fire which because of the propinquity of buildings laid agaimst each other

24. L. Stone, supra note 23, at 360-61; PRO, P.C.2/51, at 295. Bedford paid to the King $£ 2000$ for his license to build. PRO, S.P.16/287/43.

25. PRO, P.C. $2 / 48$, at $441 ;$ id. P.C. $2 / 49$, at $49 ;$ id. P.C. $2 / 51$, at 49. 
raised the specter of conflagration from small beginnings. This was of particular concern insofar as it endangered large houses, palaces, and public buildings: the royal storeliouse in East Smithfield was a matter of constant concern because of the cottages, shops, and sheds built up around it. ${ }^{26}$ There was no system of fire protection and no fire insurance, though two enterprising gentlemen, William Ryley and Edward $\mathrm{Mabb}$, in 1638 proposed a system of fire insurance, a continuous nighttime fire watch in every ward, and the provision of "fire engines" in every ward and requested a patent of monopoly for the same for 41 years. ${ }^{27}$ How real were the dangers of plague and fire was driven home mercilessly in 1665 when the worst plague simce the Black Death of the mid-fourteenth century ravished the metropolis and in 1666 when a conflagration burned down nearly the entire city of London.

The government was no less concerned with the social dislocation caused by overcrowding. An almost pathological fear of rebellion was just beneath the surface of official sensitivities. At least once a week a responsive prayer of hitany was supposed to be said in every parish church, prominent in which was, "From all sedition, privy conspiracy, and rebellion . . . Good Lord, deliver us." The Lord came uncomfortably close to failing Queen and Country in 1601 when the Earl of Essex raised a rebellion in the city of London in an attempted coup against Elizabeth. The London Mob would, in the 1640's, prove no figinent of overlieated imaginations. The contemporary notion that close physical contact of the "meaner sort of people"-and that is not an maccurate description of the social status of the vast majority of the immigrants into London-bred conspiracy growing to rebellion was exaggerated but no less devoutly beheved. Overcrowding was recognized as at least the opportunity for, though not the cause of, immorality and crime, and both were increasimgly prominent in a metropolis with no more than a rudimentary police and no system of public prosecution. Moreover, the realm having established a remarkably thoroughgomg system of poor relief by legislation in 1598 and $1601^{28}$ which depended upon virtually no broader tax base than parish rates, the possibility of London becoming a vast sink of paupers living off the rates began to become an actuality in the 1630's. This was true despite the provision-difficult to enforce in the confused conditions of London-for returning paupers to the parish of origin for relief. Increased population also put an unbearable strain on the finances and the facilities of the legally established Church of England at the parochial level. The rural clergy were dependent upon tithes on agri-

26. Id. P.C.2/52, at 668 .

27. Id. S.P.16/323, at 326-28.

28. The Poor Laws, 39 Eliz. 1, c. 3 (1598) \& 43 Eliz. 1, c. 2 (1601). 
cultural produce for their remuneration. As the rural out-parishes became urban, tithes dried up and the clergy had an increased work load with less, rather than more, recompense. In 1638 the clergy of 16 out-parishes which were already suburbia, including a number in the West End, petitioned the Privy Council for assistance in persuading their parishioners to mamtam their incomes. They met with a sympathetic but not entirely effectual response from the government. ${ }^{20}$ Indeed, in a society that found it difficult enough to raise revenue by taxation in even the most stable situation, the high degree of mobility among the new immigrants made taxation doubly difficult.

Concern with air pollution, filth in the streets, blocked streets, impaired light, and polluted water must have augmented the motivational drive; the latter particularly so, as for some years in the 1630's the main source of water to the royal palace, the springs at Piccadilly, was polluted by the buildings of a profit-minded widow, Mary Baker. ${ }^{30}$ The proclamations also noted that immigration to the metropolis tended to "depopulate" the countryside and drive up the price of food in the metropolis. Both propositions had soine merit, but were so highly conventional in the period as to amount to clichés. Elizabeth's and James I's aesthetic sensibilities were not very highly developed, but those of James' son, Charles I, were. An avid patron and collector of art, Charles was a warm supporter of Inigo Jones, his father's Surveyor General of Works froin 1615, and he continued Jones in that office. Jones was a creative architect, one of the greatest of all English architects, and his major monuments, mcluding the Queen's House at Greenwich and the Banqueting House at the palace of Whitehall, are vigorously origmal adaptations of the simple structures and understated decorative devices used by the late-sixteenth century Venetian architect, Andrea Palladio. From Palladio he also derived the ideal of harmonious urban planning: sensitivity to the use of open space among buildings complementary in design. The opportunity to realize this ideal largely escaped him, but in his designs for the Earl of Bedford's piazza in Covent Garden ${ }^{31}$ he showed what was possible. Inigo Jones' influence was probably the single most important element in James I's continued commitment to high standards in all new building, turning on the use of brick or stone rather than timber in new construction. ${ }^{32}$ Froin 1615 until 1640 - the end of the attempt to

29. PRO, P.C.2/49, at 105-06.

30. Id. P.C.2/50, at 476-77; id. P.C.2/51, at 61-62. Mrs. Baker was prosecuted in Star Chamber and ordered to make repairs. See Attorney-General v. Mary Baker, Folger, M.S. V.a.278, Pas. 10 Chas. I.

31. J. SUmmerson, ArCHTtecture IN BRitain, 1530-1830, chs. 7-12 (1953).

32. See proclamation for building, June 16, 1615, Short Title Catalogue 8523 [hereinafter cited as STC]. 
control building-Inigo Jones was the technical arbiter of the successive commissions for building and, after the accession of Charles I in 1625, the leading spirit of the commissions as well. He did an enormous amount of work alone, or with a few other commissioners joined with him, in viewing and recommending action on buildings already constructed, in process of construction, or planned. He was indefatigable in checking plans and designs. He sustained the commissioners, and the King and Council, in their determination to control building. Perforce, he shifted the direction of the control program away from the purely negative prohibitory emphasis that it had had in the beginning to a more positive and creative emphasis. This shift was a mixed blessing, as events would prove. ${ }^{33}$

\section{B. The Beginning of Building Control: Elizabeth l's Reign}

Queen Elizabeth I issued the first proclamation in restraint of new building in London and three miles beyond its gates on July 7, $1580 .{ }^{34}$ It was a blanket prohibition against all new building and dividing of tenements. I have discovered no evidence that any real attempt was made to enforce it until 1590. Between October 1590, and April 1592, a number of parties were convened before a special commission joined with the Privy Council, sitting in the Westminster Justice Hall, presided over by Sir Gilbert Gerrard, Master of the Rolls, formerly the Attorney-General. ${ }^{35}$ The exact number is unknown. We have only the 81 recognizances actually estreated later. We are, however, probably justified in supposing that a considerable number of others were presented before the special commissioners and bound in recognizances on the same conditions, and that they, unlike these 81 , performed the conditions and had their recognizances cancelled. The 81 known violators of the proclamation of 1580 were bound in either $£ 10, £ 20, £ 40$, or $£ 100-41$ in the latter sum-to perform various conditions. The conditions can be divided into four categories, one or more of which might apply in any case: one, to put out tenants or not to receive tenants; two, to cease building or to restore a building to approved use; three, to keep the parish safe from poor relief liability for any tenant allowed to continue; and four, to pay the fine imposed by Star Chanber for delinquency. ${ }^{36}$

33. See text following note 58 infra.

34. STC 8122.

35. The style was (in translation from the Latin) "before Gilbert Gerard, knight, and others of our commissioners and also before us and our council at Westminster." PRO, E.159/423, Tr.44 Eliz., rot.95.

36. Id. The commissioners' certificate to the Star Chamber of the first round of recognizances taken, dated Dec. 14, 1590, is in id. E.163/15/10. 
The next round of major activity came in 1597 . The commissioners "for examining and reforming new erected buildings" in London and the suburbs made a return to the Privy Council concerning the buildings constructed between July 7, 1580, the date of the first proclamation, and July 20,1597 . The only extant return is for various western wards and out-liberties of the city of London. The building commissioners distinguished between those builders who had already answered before the Privy Council for their new construction and those who had not. ${ }^{37}$ At least eight of the latter, with four sureties, were bound in various sums on the same conditions as the recognizances of 1590 to $1592 .{ }^{38}$

The first report of a trial in Star Chamber for violation of the proclamation agamst building dates from 1598. The Attorney-General prosecuted John Cryspe of Middlesex and Richard Griffith of London for building tenements in London against the proclamation. ${ }^{30}$ To the "good example" of others, they were sentenced to a fine of $\$ 20$ each, imprisonment at the Queen's pleasure, their tenements to be demolished after the present tenants liad left them, and the timber of the houses to be sold for the aid of the poor of the parish. They were also each bound with sureties in $\$ 40$ to perform the sentence of the court. $^{40}$ From the vantage point of the last decade of building control, this case and the decree in it constituted the springing point for all subsequent Star Chamber prosecutions.

In 1601 there is a glimpse of another flurry of activity, in the certificate of the building commissioners as to building in the West End suburb of St. Martin's-in-the-Fields. ${ }^{41}$ In the next year there was a further spate of binding over of building constructors, although apparently of a much more limited scope than the previous periods of recognizance ultilization. Four Holborn developers were bound, three in $£ 40$ and one in $£ 100$, on the usual conditions. ${ }^{42}$ The second proclamation against building was issued about the same time, in June 1602 , but the four Holborn developers were probably acted against pursuant to the 1580 proclamation. The new proclamation was largely a reiteration of the first. It noticed the recent prosecutions and demanded more effective action by civic officials in discovering and presenting violators. ${ }^{43}$ Its issuance did signal a tough line against

37. Id. E.163/15/4.

38. Id. E.159/423, Tr.44 Eliz., rot.95.

39. See text accompanying note 64 infra.

40. Inner Temple Library, London, Petyt MS. 511, v.13, f.117; PRO, E.159/423, Tr.44 Eliz., rot.95.

41. PRO, E. $147 / 2 / 19$.

42. Id. E.159/423, Tr.44 Eliz., rot.95, id. Mich. $44-45$ Eliz., rot. 246.

43. Proclamation of June 22, 1602, STC 8292, reprinted in 7 RYMER's FoEDERA (II), at 37-39 (1742). 
builders. The 95 recognizances ranging back to October 1590 , were estreated in July 1602, one month after the issuance of the second proclamation; the recognizances of the four Holborn developers were estreated in November. ${ }^{44}$ These 99 recognizances amounted to $£ 5715$ they probably did not actually bring so much, for the machinery for levying debts due the crown was notoriously ineffective, dependent as it was on the weakest link in government, the sheriff-but it was already becoming evident that if prosecution of violators did not bring abatement, it might bring some revenue.

From the outset in the 1590's the building commissioners played a major role in the administrative implementation of the proclamations against building. Despite the apparent blanket prohibition of building by the first proclamation, in fact the commissioners had early recognized that building was going on and that their task was to slow it down, particularly by pressure to build only on old foundations, and to prevent the worst excesses of dividing tenements and converting sheds and the like to dwellings. This was the thrust of the recognizances of the 1590-1602 period, and it was the governing policy of the commissioners until the early 1630's.

\section{From Restraint to Standards: James I's Reign}

James I issued twelve proclamations for control of building, as against two of his predecessor, Elizabeth, and two of his successor, Charles I. The first proclanation, issued just a year after James' accession, was supplementary to Elizabeth's second (of 1602). ${ }^{45}$ It contamed the significant addition that any new building was to be of brick or stone or both, and that the street front was to be uniforn with the rest of the buildings on the street. The second Elizabethan proclamation allowed new construction on old foundations, but had been silent on the matter of building standards. Thus, James' concern with building standards was manifest from the outset of his reign, though it reached full fruition only with the later proclamations. On October 12, 1607, James issued a comprehensive proclamation which confirmed the 1602 proclamation's provisions against building on new foundations and dividing of tenements, prohibited lodging in cellars, and reiterated the standards set forth in his first proclamation. ${ }^{46}$ James' third proclamation, in 1608, was explanatory of the 1607 proclamation. ${ }^{47}$ Two years later, in 1610, under pressure from

44. PRO, E.159/423, Tr.44 Eliz., rot.95, id. Mich. $44-45$ Eliz., rot.246.

45. Proclamation of Mar. 1, 1605, STC 8370, calendared in 1 J. CRAWFORD, Biblotheca Lindestana, Tudor-Stuart Royal Proclamations No. 1011 (1910).

46. Proclamation of Oct. 12, 1607, STC 8407, 1 J. CRAwFORd, supra note 45, No. 1049.

47. Proclamation of July 25, 1608, STC 8420, 1 J. CRAWFORD, supra note 45, No. 1063. 
Parliament, which liad questioned the increasing use of proclamations as positive law by James, the King rescinded, inter alia, the three previous building proclamations of his reign with provision for them being incorporated into one proclamation. ${ }^{48}$ This rescission introduced ambiguity into the prohibitory status of building control since there does not appear to have been issued a new proclamation incorporating the provisions of the three rescinded proclamations, and only the 1607 proclamation specifically prohibited building on new foundations, subdividing of tenements, receiving of inmates, and lodging $\mathrm{m}$ cellars. Therefore, subsequent Star Chamber prosecutions were brought under the 1607 proclamation only to be dashed when the defendants pleaded the rescission of that proclamation. ${ }^{49}$ In 1611 , three proclamations, the latter two each superseding the previous one, followed each other in quick succession. ${ }^{50}$ These were short proclamations spelling out in greater detail standards for building. With James' next proclamations, in 1615 and 1618, emphasis swung back to the Elizabethan preoccupation with prohibition of all new building, or at least very tight restriction on new building. ${ }^{51}$ This swing did not last long; in 1619 , James issued the most comprehensive building proclamation of the reign directed not to restraining new construction but to establishing minute standards both for construction and ornamentation of new buildings. ${ }^{52}$ The standards prescribed a Palladian simplicity that clearly demonstrates the hand of Inigo Jones, and with this proclamation building control enters firmly into the phase of quality control rather than prohibition of or extensive restraint on construction itself. $^{53}$

James' proclamations, insofar as they specified punishment for violation of their provisions, explicitly directed prosecution in Star Cliamber. The proclamation of 1608 referred to a number of violators having been made "examples" to others in Star Chamber.

48. Proclamation of Sept. 24, 1610, 1 J. Crawford, supra note 45, No. 1096; see text accompanying note 55 infra.

49. See text accompanying notes $56-57$ infra.

50. Proclamation of July 22,1611 , STC $8470,1 \mathrm{~J}$. CrAWFord, supra note 45 , No. 1114; proclamation of Aug. 3, 1611, $1 \mathrm{~J}$. CRAWFORD, supra No. 1115; proclamation of Sept. 10, 1611, STC 8471, 1 J. CRAWFord, supra No. 1117.

51. Proclamation of July 16,1615 , STC $8523,1 \mathrm{~J}$. CrawFord, supra note 45 , proclamation of July 20, 1618, STC 8574, 1 J. CRAWFORD, supra No. 1218.

52. Proclamation of Mar. 12, 1619, STC 8603 \& 8604, 1 J. CRAWFORD, supra note 45, No. 1248.

53. The last two proclamations of James' reign, July 17, 1620 [STC 8639, 1 J. CraWford, supra note 45, No. 1285] and July 14, 1624 [STC 8733, 8744, and $1 \mathrm{~J}$. CRAWFORD, supra No. 1381] were primarily explanatory of the previous proclamations issued since 1611. 
These examples were of recent vintage. In February 1607, five builders were fined in sums ranging from $£ 30$ to $£ 100$ for building contrary to the proclamations and three tenements were ordered demolished. ${ }^{54}$ On October 16,1607, the day of publication of the comprehensive Jacobean proclamation of October 12, 1607, Solicitor-General Sir Francis Bacon proceeded ore tenus, that is, without written information, against a cook and a scrivener who, on their own confession, had erected buildings in contravention of the various proclamations, including the one just published. ${ }^{55}$ The case gave rise to one of those full-blown oratorical performances by bar and bench that occasionally marked proceedings in Star Chamber in the first decade of James' reign when Ellesmere presided as Lord Chancellor, Sir Edward Coke sat as Chief Justice, and Sir Francis Bacon appeared for the King. All three roundly condemned building, as far as we can learn from the confused report of the case, Coke holding that such buildings were against both the Common Law and the King's prerogative, and characteristically dredging up from Bracton, Britton, and the early Year Books that "as it is the kinge's prerogatiue, so it is the auntient lawe that no noble man or subiecte whatsoeuer maye buylde any forte or howse with battlementes ...."56 Ellesmere conceded that while the king might not take one's lands and goods and give them to another, "where the Common state or wealthe of the people or kingedome require it, the kinge's proclamacion bindes as a law, \& neede not staye [for] a parliamente; and as a father saythe, when lawes are in making euery man may speake, but being made"57 judgment is according to laws. The Recorder of London, also appearing for the King, pointed out that a commission appointed by Star Chamber two years before had found 300 violations of the proclamations and in four large houses some 8,000 inhabitants of whom in the great plague 800 in one house alone had died. The defendants in this case were fined $£ 100$ and $\$ 200$, respectively, and immediate demolition was ordered in the case of one and conditional demolition im the case of the other. ${ }^{58}$

Two other major prosecutions extant for the reign of James I date from 1618 and 1622. Both were brought for violation of the proclamation of 1607. Attorney-General v. Wright $(1618)^{59}$ is in-

54. J. Hawarde, Les Reportes del Cases in Camera Stellata 318-19 (1894).

55. Id. at $328-30$.

56. Id.

57. Id.

58. Id.

59. PRO, St.Ch.8/28/4. 
triguing. The information alleged that despite his being committed by a magistrate pursuant to the proclamation of 1607 , then released on recognizance not to complete the building in the West End which he had begun in 1616, Wright had continued to build. The Attorney-General investigated the inatter and ordered him to stop building after Wright confessed that he had exceeded the proclamation in building on about one-third new foundations. The Attorney-General told Wright that the King had given him specific orders to suppress all building against the proclamation, "and that he [the Attorney-General] should be driven by the dutie of his place to question him in . . . Starchamber for the same" and to sue process to levy the recognizance. Despite this and several restraining warrants directed to him by the commissioners for building, Wright continued to build. Process to quit the premises was issued by the Chief Justice of the King's Bench and served by constables, who were assaulted by the Wrights and 29 others who were armed and barricaded in the place. A full-scale riot was alleged to have taken place, the sheriff raising the posse, and the rioters finally fleeing by the rear. Afterwards, local magistrates at the Chief Justice's behest viewed the site and found all new foundations, upon which Wright was again ordered to cease building. Nonetheless, he continued and completed the building. In their answer, the defendants pleaded not guilty to the misdemeanors charged, but submitted that their case did not fall within the proclamation of 1607 , since their house was built on old foundations for the greatest part and the rest on an inner court and that it was for their own use and not for tenancy. They argued further that the proclamation of 1607 was, with three other proclamations (1580, 1602, and 1605), "drawn together" and clarified in a proclamation of September 24, 1610, which then superseded all previous proclamations. Since then, they argued, two further proclamations, August 3,1611, and September 10,1611, prohibited all building except upon old foundations or on an inner court. Therefore, they were informed by their counsel that the proclamation of 1607 was "expresly repealed and determyned." rect, for the proclamation of September 24, 1610, explicitly "determined" all previous proclamations, including that of $1607 .{ }^{\circ 1}$ The Attorney-General ought to have brought the prosecution on the proclamations of 1611. That nothing more than the pleadings in this case is extant supports the inference that the case proceeded no further because it was grounded on a repealed proclamation. Surprisingly, the only other Star Chamber information extant for the

60. Id.

61. 1 J. CRAWFORD, supra note 45 , No. 1096. 
reign of James I, Attorney-General v. Baker (1622), ${ }^{62}$ was also grounded on the 1607 proclamation, and the defense pleaded in bar that the proclamation was repealed.

Virtually all the Privy Council records and complementary state papers from the beginning of the reign of James $I$ to 1613 were destroyed in a fire in Whitehall in 1618. This effectively obscures the work of the commissioners for building and the Privy Council in attempting to control London building from 1603 to about 1613 . It appears, however, that the commissioners followed the enforcement pattern established during Elizabeth's reign. ${ }^{33}$ Certainly until the 1630's the commission for building, rather than the court of Star Chamber, was the key to enforcement. This corresponded to the greater emphasis James and his Surveyor-General of Works, Inigo Jones, placed on a rational and creative approach to building in the metropolis.

The shift of emphasis from restraint to standards for building did not, however, produce the hoped-for benefits. The essential priority of the commissions cught to have been prohibitory. Not until new construction was halted could the resources of government of that age have seriously sustained a program of urban planning and highstandard building. As it was, construction was not halted, creative innovation was piecemeal and even precicus, and the onset of civil war arrested the creative and removed the possibility of halting the destructive urban paralysis induced by substandard and overcrowded housing.

\section{Commonweal and Revenue: Charles I's Reign}

Charles I ascended the throne on March 27, 1625. On May 2 , he issued the most comprehensive and the longest proclamation to that date in restraimt of building and for enjoming standards of construction and materials. ${ }^{64}$ From thickness of walls, to height of docrs, to depth of cellars, proportions of windows (higher than wider, to let in light and air), to straight walls, to the exact manufacture and quality of bricks, the proclamation manifests the professional hand of Inigo Jones. This minuteness would be exceeded only by the second, and last, proclamation of the reign, that of $1630 .^{65}$

62. PRO, St.Ch.8/30/17. A number of builders were fined from $£ 21$ to $£ 40$ for building timber-fronted new houses, instead of stone or brick faced structures, in violation of the proclamations, and were ordered to reconstruct the fronts, by decree of Star Chamber, January 27, 1619. PRO, S.P.14/105/66.

63. See text accompanying notes 33-44 supra.

64. Proclamation of May 2, 1625, STC 8771 \& 8772, reprinted in 8 RYMER's FoEDERA (I), at 24-27 (1742).

65. Proclamation of July 24 [or 16], 1630, STC 8958 \& 8959, reprinted in 8 RYMER'S FOEDERA (III), at 111-14 (1742). 
The Privy Council records evidence a quickening of activity on the part of the commissioners for building from Charles' accession. The first commission of the new reign was tested on May 30, 1625. A year later the Privy Council determined to prosecute violators and on August 14, 1626, directed the Attorney-General to bring information in Star Chamber agamst those presented to him by the commissioners as violators of the proclamation. ${ }^{66}$ Unhappily, the period from 1625 to 1630 is the sparsest for records of Star Chamber, and though there is abundant data on the activity of the Privy Council in support of the building commissioners, there is extant only one case in Star Chamber to indicate the extent of prosecutions.

Attorney-General v. Ward, ${ }^{67}$ sentenced November 19,1628 , was of major importance in the development of the powers of Star Chamber, and derivatively of the Privy Council, to deal with violators of the proclamations against building. According to the report by John Lightfoot of Gray's Inn, the defendants' violations of the proclaination of 1625

were punished as offences of common nuisance and so by the common law punishable, and [the buildings] to be demolished and removed and the parties were fined for this to the king. Richardson [Chief Justice, Kings Bench] said that doubtful things the King was not able to settle by proclamation, but for [a] thing that is an offence by the law, or for other emergent cause of state that many times cannot await [a] parliament, these the King can by his proclamation govern, as command his subject not to pass overseas, etc. The King can pardon the fine itself but not the offence of nuisance. ${ }^{68}$

Richardson's opinion was fairly representative of conventional doctrine on the authority of proclamations. In Attorney-General v. Cryspe $e^{69}$ (1598) the court had decreed the demolition of the defendants' buildings, but on what legal grounds is more than unclear. None of the successive proclamations specified particular pains or penalties. The proclamations directed that violators be cited by the commissioners, civic authorities, or magistrates to appear before the Privy Council or in the Star Cliamber "to answeare such their Contempts, and to undergoe such Sentence as by that Court shall be given against thein."70

66. Commission of May 30, 1625, 8 RXMER's FOEDERA (I), at 70-72 (1742); ACTS OF THE PRTVY Council, 1626, at 184 (1938) [hereinafter cited as ACTS].

67. Harvard Law School, L.MS. 1128, No. 60 [Harvard Law School is hereinafter cited as Harv. L.S.].

68. Id. (translation by author).

69. Inner Temple Library, Petyt MS. 511, vol. 13, f.117; see text accompanying note 29 supra.

70. Proclamation of July 24, 1630, 8 RYMER's FoederA (III), at 111-14 (1742). 
Even if demolition could be grounded on specific wording in the proclamation, it was accepted that a proclamation could not legally justify destruction of real property. ${ }^{71}$ Nevertheless, the Privy Council in 1627 lashed out at one particularly obnoxious and contemptuous builder, who had erected a house on the King's own ground near the parkament house, enjoining him to prove to the commissioners within 14 days that the house was on old foundations or the commissioners were to have it demolished. ${ }^{72}$ The sentence in Ward's $\mathrm{Case}^{73}$ and the Star Chamber order a year later directing a writ of assistance to the sheriff to demolish Ward's and the other defendants' buildings made demohtion an ordinary feature of building control. Henceforth both the Privy Council and the court of Star Chamber ordered it as a matter of course in heinous cases. ${ }^{74}$

The prosecution of John Moore early in $1634^{75}$ by the Attorney-General was the signal for a tough new policy against builders and developers. It was a policy directed less at preventing building than making the builders pay dearly for the privilege of building. It reflected the government's need for revenue in the aftermath of the disastrous failure in the previous two decades to secure adequate extraordinary revenue from parliament. With Charles' 1629 resolution that he would never summon another parhament, taken as he dissolved his third parliannent, the need became imperative. The extra-parliainentary financial expedients that Charles resorted to in the 1620 's, and which he would lean upon yet more heavily in the 1630 's, were either one-time-only devices, such as privy seal loans, forced loans, and composition for knighthood, or if continuous, such as ship money, the revenue was restricted to a specific purpose. ${ }^{76}$ Revenue raised as a profit of or incidental to justice was, on the other hand, virtually limitless.

Beginning in 1631, with heaviest concentration in 1632 to 1636 , the Attorney-General brought some 175 prosecutions in Star Chamber, of which about 40 came to trial and judgment, all of which are best characterized as prosecutions for the purpose of raising revenue. The ostensible reason for the prosecutions was the commonweal. The defendants were depopulators, ${ }^{77}$ officials who extorted fees, ex-

71. See text accompanying note 91 infra.

72. Privy Council order, Sept. 2, 1627, AcTs, 1627-1628, at 1-2 (1949).

73. See text accompanying notes $62-63$ supra.

74. Harv. L.S., L.MS. 1128, no.128, order in Ward's Case, Mich. 1629; AcTs, 1629-30, at 31-32, 327, 410-11 (1961). See text accompanying notes 99-101 infra.

75. See text accoinpanying notes 10-14 supra and note 76 infra.

76. T. BARNes, SOMERSET 1625-1640: A County's Government DuRING The "Personal RULE" 143-71, 203-43 (1961).

77. A person who depopulates the rural area by enclosing and converting arable land to pasture. 
porters of prohibited commodities, grain-hoarders, deceifful manufacturers and merchants, gentlemen who did not reside at their country seats to fulfill their social and political obligations, sheriffs malfeasant in office, infringers of patents of monopoly, victuallers who sold meat in Lent, and, most significantly, violators of the building proclamations. In every case a large fine was sought to the terror of others and a declaratory judgment of Star Chamber which could be used as a threat agamst like offenders to persuade them to compound $^{78}$ for their offences with special commissioners appointed for the purpose. ${ }^{79}$ The warrant for a grant of the receivership of fines and compositions from builders, given to a courtier early in 1640, makes clear that revenue was the object of the enforcement of the proclamations against building. The commissioners, now presided over by the Lord Treasurer, had been given authority to order demolition of buildings or to continue the same upon "moderate fines." The new office of receiver was to discover and prosecute those who did not come in and make composition to compound for their offenses. ${ }^{80}$

John Moore's prosecution was the first of 14 building prosecutions brought by the Attorney-General between 1634 and 1639.81 Moore las the distinction of being the subject of the most suminary prosecution in the later period of Star Chamber. $\mathrm{He}$ was called to the sitting of the commissioners on January 22, 1634, to defend his 42 buildings. ${ }^{82}$ At 10 a.m. the commissioners commanded him to tell the Attorney-General of all the buildings he had built on new foundations. His examination by and confession to the AttorneyGeneral is dated the same day. He admitted that none of the buildings was on entirely old foundations. Two days later, Moore was before the court of Star Chamber and the Attorney-General proceeded against him ore tenus, that is, without written information, the defendant having confessed the fact and thereby obviating pleadings and proofs. The Attorney-General construed the facts and argued at

78. To settle debt by compromise payment of less than the total claim.

79. Barnes, Due Process and Slow Process in the Late Elizabethan and Early Stuart Star Chamber, 6 AM. J. LEGAL Hist. 335-36 (1962).

80. Bodleian, Bankes MSS. 55/80, warrant for grant to Henry Jermyn, Esq., Marcb 3, 1640.

81. Besides Moore, William Smith was prosecuted ore tenus (without written information). See text accompanying note 79 infra. The twelve other cases, brought by the Attorney-General by information were against Henry Standish (Pas. 10 Chas. I), Mary Baker (Pas. 10), John Earl Clare (Pas. 11), William Treveale (Tr. 11), Edward Jarratt (Mich. 11), Richard Garbrand (Mich. 11), Edward Spence (Pas. 12), William Smith (Tr. 12), Richard Hyde (Pas. 13), William Townsend (Mich. 14), Raphe Macro (Hil. 14), Abraham Balkley (Mich. 15). Folger, MS. V.a.278, sub "A.".

82. See text accompanying notes 10-14 supra. 
length the precedents for demolition, all of them, imcidentally, from the twelfth and thirteenth centuries, concluding that "nuisances are like weeds in a garden." Moore's defense aggravated more than extenuated his offence. He claimed the benefit of the King's coronation pardon. The court held that the words of the pardon did not cover this offence and, moreover, that he had continued the nuisance simce the pardon. $\mathrm{He}$ was committed to prison, fined $\$ 1000$, and ordered to demolish the buildings by the next Easter (April 6) or be fined a further $\$ 1000$. The first fine was estreated the day of the sentence, January 24-unusual celerity since fines were generally estreated soine months after sentence. On April 25, the Attorney-General moved the court to issue a writ to the sheriff to demolish the buildings. The writ was granted. Five days later the court ordered the estreat of the second $£ 1000$ fine. The demolition continued through the summer. Moore petitioned the king to remit the second fine of $£ 1000$ (which was granted). Apparently, he also prevailed upon Attorney-General Noy to spare a few of the buildings. His failure to pay the entire $\$ 1000$ original fine resulted in the extending (seizure upon judgment) of 20 houses of his on the Strand in February 1636 (annual value $\$ 100$ ) and a further 10 houses ( $£ 50$ ) in June 1637, which were not restored to him until Hilary term $1640 .{ }^{83}$

The developers had good reason to feel terrified. As if to punch home the lesson, the Attorney-General on January 22, 1634, also proceeded ore tenus against a man of lesser means, William Smith, for building in Lincoln's Inn Fields. The court noted that his house had been set up "by sufference" of the commissioners for buildings, but nevertheless, he was committed to prison and fined $\$ 200$, and ordered to demolish it by Easter or pay a further $£ 200$ fine. ${ }^{84}$ His fine was estreated within a few days of his sentence.

The judicial climax to the prosecutions came in a general decree of Star Chamber of February 14, 1637, drawn "by the advice" of the Lord Keeper, the Lord Privy Seal, and all the judges of the courts of King's Bench, Common Pleas, and Exchequer, against dividing teneinents. ${ }^{85}$ The decree provided, inter alia, for the binding over in good sureties of landlords of tenements divided within the past seven

83. Moore's case, Bodleian, Bankes MSS. 18/35; Harv. L.S., L.MS. 1128, No. 249; British Museum, Harley MS. 4022, ff. 1 \& 7v; British Museum, Additional MS. 11764, f. 1; 2 Rushworth's Historical Collection (II) App. 66-67 (1721); Berkshire Record Office, Trumbull Additional MS. 37; PRO, E.159/473, Hil. 9 Chas. 1, rot. 17; id., E.159/479, Hil. 15 Chas. 1, rot. 37.

84. 2 RUSHWORTH's Historical Collections (II) App. 67 (1721); Huntington Library, Ellesmere MS. 7892 (note of the case by the Earl of Bridgwater).

85. A Decree in Starre-Chamber: concerning Inmates and Divided Tenements (1636/37), STC 7756. 
years to remove the tenants and to restore the tenements to their previously undivided state within one year as well as to pay the maintenance of pauper tenants in the same retroactively from the previous June. Provision was made to act agamst landlords of tenements divided even prior to seven years before; and landlords and builders, who in the future built or divided tenements, were given one month to pull down or reform the same. Failure to perform any part of the decree was held to be contempt of the court of Star Chamber, and attachment would be awarded against the contemnor with double costs to the prosecutor. All subsequent activity by the commissioners for building, the civic authorities, and Star Chamber was apparently founded on this decree, which was primted by the King's printer and widely published. ${ }^{88}$

How much revenue was brought into the coffers of a financially straitened government by building prosecutions eludes us. The amount of activity by the Attorney-General, the prosecutions in the Star Chamber, and the continuous activity of the Privy Council from 1634 to $1640^{87}$ in pressing prosecution in Star Chamber, in cajoling the commissioners for building, in writing sharp letters to the sheriffs of London and Middlesex, the Lord Mayor of London, and the magistrates of the metropolis, and in demanding from all officials involved a full account of new building at regular intervals suggest that the revenue gleaned was worth the effort. A glimpse is caught of a racket in counterfeit licences to build, which did not stop at forging the signature of the Earl Marshal, the chief commissioner for building. ${ }^{88}$ A list, dating from about 1638, gives the names of almost four hundred and fifty persons who had compounded for building contrary to the proclamations and the number of buildings for whicl each was responsible. Unfortunately the amounts for coinposition are not given, but any estimate that comes close to the profits from the analogous prosecution of depopulators- $\left\{30,000\right.$-is plausible. ${ }^{89}$ By the end of 1640 , the attempt to

86. Id. Pursuant to the decree, the civic authorities of London, Southwark, and Lambeth made a ward-by-ward and parish-by-parish return of new buildings and divided tenements of the previous seven years, in May 1637, which comprises a large MS. volume in PRO, S.P.16/359.

87. See Attorney-General Bankes's papers in Bodleian, Bankes MSS.; the Privy Council activity is recorded in the Privy Council Registers, PRO, P.C.2/43-53; the activities of the building commissioners can be found in PRO, S.P.16, especially the volumes for 1633-34.

88. Bodleian, Bankes MSS. $63 / 29$ (the Attorney-General's examination of Willian Whetson, Jan. 11, 1637). The counterfeiter, John Elmestone, was prosecuted ore tenus in Star Chamber on Jan. 27, 1637, and sentenced to $£ 1000$ fine and pillory. PRO, S.P. $16 / 345 / 24$.

89. PRO, S.P.16/408/65. Depopulation prosecutions yielded about $£ 30,000$. See T. BARNES, supra note 76, at 336. By Easter 1635, fines on violators of building proclamations during the preceding decade had brought in $£ 8,5476$ s. 8d. PRO, S.P.16/285/89. 
control building was just one of many "grievances to the subject" which the Long Parliament, bent on dismantling Charles I's personal rule of the preceding eleven years, would use to flay the King's ministers and to attack the court of Star Chamber. Raphe Marco, sentenced in Star Chamber for violation of building control, made a scathing attack on the justice of his sentence in a petition to the House of Lords. ${ }^{90}$ Two of the 204 articles in the Commons" "Grand Remonstrance" of December 1641 against the governance of the personal rule imcorporate complaints agamst building control: article 28, "The restraint of the liberties of the subjects in their habitation, trades and other interest"; and article 30, "The sale of pretended nuisances, as building in and about London."

The last Privy Council order concerning building, April 16, $1641,{ }^{92}$ came ten months after the previous one, a few days before the great chief minister of Charles I, the Earl of Strafford, was declared by the House of Commons to be a traitor, and a hittle more than two months before the King reluctantly assented to the act of parliament abolishing the Star Chamber. The Privy Council ordered the AttorneyGeneral to take a "speedy and effectuall course according to law" against one Mrs. Bele, whose newly erected building adjacent to the Queen's palace at Somerset House was "unfitt" and an "annoyance," whereby "to prevent and remove the nuisance." 3 The moderateness of the order, and the ambiguity as to the "course" to be taken, are striking. Proclamations, commissioners, receivers of fines and compositions, even the Star Chamber itself, counted for little or nothing in the first year of the English Revolution.

\section{III}

\section{PREROGATIVE AND PROCLAMATION: THE LOST OPPORTUNITY}

Queen Elizabeth I can hardly be taxed with not forseemg from the vantage point of 1580 that the regal prerogative to advance the commonweal and to repress activity inimical to the state and the commonweal by the device of proclamation would be of little account in 1641 . The use of proclamation to give force to the law, whether common or statute law, was unquestioned in the sixteenth century. For a brief period under Henry VIII a statute declared that royal proclamations, promulgated with the advice of the King's Council under circumstances whereby to wait for parliamentary legislation there "might

90. Macro's petition, Feb. 5, 1641 is in H.L.R.O., Main Pprs., supra note 6 (1-18 Feb. 1640/1) f.56.

91. The "Grand Remonstrance" is in 4 Rushworth's Historical Collections 437-51 (1721).

92. PRO, P.C.2/53, at 122 .

93. Id. 
happen great prejudice" to the realm, "shall be obeyed, observed, and kept as though they were made by Act of Parliament for the time in them limited . . . .94 The repeal of this statute in 1547 did not affect the use of proclamations, though the absence of such a statutory basis for proclamations left them wholly in the area of the royal prerogative.

Elizabeth, even more than Henry VIII, used proclamations as legislation. The proclamation was a simple and a supple imstrument. It was promulgated as an act of the monarch's own will, usually but not necessarily with the advice of his Council, and it did not involve the detiberation and consent of the houses of parliament. It could be much more discursive and less formal than an act of parhament. It could be repealed, modified, or interpreted by supplementary proclamation, with ease. By contemporaries it was considered "positive law," albeit nonparliamentary law. ${ }^{95}$ The very limitations on it, in coinparison with parliamentary (statutory) law, gave it an unusual force. The clearest declaration of those limitations is afforded by Riclard Crompton: "Note that the King is not able by his proclamation to alter the law, but can make proclamation that if anyone acts against the content of the proclamation he will incur his Majesty's indignation; but paim of forfeiture of his land or loss of his life, [these] without parhament cannot be."96 If the King cannot alter the law by his proclamation, then there is a presumption that the proclamation is a declaration in furtherance of the law, common or statutory. This presumption sets the court that has jurisdiction on the hunt for the law upon which the proclamation is founded. The proclamation's implicit invitation to ground it in the law is reflected in Coke's famous dictum: "Note, Proclamations are of great force, which are grounded upon the lawes of the Realme." The expression of the regal attention to an area of the law in a proclamation was a spur to judicial interpretation and, possibly, expansion of the law. In addition, because a proclamation could not touch land or life, violation of it constituted misdemeanor, punisliable by fine and imprisonment at the King's pleasure - this was the consequence of the King's "indignation." Prosecution for misdemeanor could be brought in the common law courts-King's Bench, courts of oyer and terminer and of gaol delivery, or quarter ses-

94. 31 Hen. 8, c. 8 (1539), repealed 1 Edw. 6, c. 12, sched. 4 (1547); see Elton, Henry VIII's Act of Proclamation, 75 ENG. Hist. REv. 208 (1960).

95. T. EgERTON, A DISCOURSE UPON THE EXPOSICION AND UNDERSTANDINGE OF Statutes 103-04 (S. Thorne ed. 1942) (written about 1560).

96. R. Crompton, L'Authoritie et JuRisdiction des Courts f. 14 (1594) (translation by author).

97. 3 E. COKE, INSTITUTES 162 (1644). 
sions-either by indictment or presentment. However, the required indictment or presentment had to be founded on an explicit law, and the very inexplicitness of the proclamation with respect to the law put it beyond the cognizance of the criminal jurisdiction of the common law courts. There was, therefore, no alternative but to enforce proclamations in the one criminal court which did not demand the legal formalness of the indictment or presentment: Star Chamber. Finally, violation of the proclamation was contempt of the regal will, to the King's "indignation," and in concrete procedural terms this mean that none could move the court to enforce a proclamation save the King's own counsel, the Attorney-General. This gave the monarch complete control over prosecution for violation of the proclamation. Here was a marked difference with statutory misdemeanors; a statutory misdemeanor could be prosecuted by any of the King's subjects, the party injured, or, if it specified a particular penal sum for violation, by an informer on behalf of the King and himself. In the subtle and politically tender areas in which Tudor and Stuart monarchs used proclanations, the King's monopoly of prosecution was a major safeguard for him.

In the first decade of the seventeenth century it was possible for the two legal giants of the age to hold largely opposing views of the nature, effectiveness, and lawfulness of proclamations. Their views remained unreconciled and unsettled. In the so-called Case of Proclamations (1610), ${ }^{98}$ Chief Justice Coke, with Chief Justice Fleming of the King's Bench, Chief Baron Tanfield and Baron Altham of the Exchequer, "resolved," upon conference with the Privy Council, that the King could not by his proclamation create an offence which was not an offence before; that the King had no prerogative but that which the law of the land allowed him; that im order to prevent offences the King might by proclamation admonish his subjects to keep the laws upon pain of punishment to be inflicted by those laws; that if the offence was not punishable in the Star Chamber the prohibition of it by proclamation could not make it punishable there. Coke, who alone reports this "resolution," concludes that "after this resolution no proclamation imposing fine and imprisonment was afterwards made, etc." It is questionable whether any proclamation before the "resolution" imposed fime and imprisonment exphicitly; it is certain that a nuniber of proclamations afterwards were the basis for prosecutions that resulted in fine and imprisonment. While it would be pleasing to believe that all the proclamations enforced by Star Chamber after

98. 12 Coke's Reports f. 74 (1777).

99. Id. 
1610 were thoroughly grounded on explicit law, in fact many of them were not. We are dogged by the unreliability of Coke's dicta on delicate matters of constitution and politics after 1608. Their unreliability is lieightened by the questionable textual validity of the twelfth volume of Coke's Reports. In any event, the "resolutions" of four judges out of twelve, delivered neither in open court nor upon conference of all the judges in Serjeants' Inn, on a question not arising out of litigation, were of no binding authority then.

Similarly, Lord Cliancellor Ellesmere's analytical notes on proclamations, still extant among his papers, were not of binding authority, yet they indicate another view of proclamations which was closer to the practical role proclamations played in the period: "The kinge by his prerogative may restreyne thinges agaynst the commenweale, as well in tanto, as in toto, and maye also restreyne the libertie of his subjectes in thinges that are agaynst the commenweal. And what is agaynst the commenweale, the king and his counsell are to judge and determyne." ${ }^{100}$ Among the examples of proclamations to implement this prerogative power are "New buildings, dividing of houses, mmates."101 Coke and Ellesmere were operating on different planes of interpretation, of authority, and perliaps even of law. As it happened, the courts-common law as well as Star Chamber-accepted in practice the burden of Ellesmere's argument. Nonetheless, the courts, mcluding the Star Chamber in the case of proclamations against building, did so by the device suggested by Coke's argument, although not for such sweeping reasons as Coke's "resolutions" would require.

In Ward's Case ${ }^{102}$ and Moore's Case ${ }^{103}$ the court of Star Chamber was at pains to find that not only had the defendants violated the proclamations by their building but that they liad also created a common nuisance. This concern did not grow out of any sensitivity to fining and imprisoning the defendant for violation of the proclamation. It stemmed from the fact that the court intended to touch his property in a very direct and concrete way-by demolishing his buildings. At no time in the history of the Tudor and Stuart government was there a scintilla of authority in law for the position that buildings adhering to the realty could be demolished by virtue of a proclamation. But abatement of a common nuisance was well established in law. The standard justice's handbook of the period, in discussing the lawful-

100. Huntington Library, Ellesmere MS. 456. These notes can be dated between 1610 and 1617; the most likely date is 1610 , when the issue of proclamations was raised in Parliament, which gave rise to the so-called Case of Proclamatlons.

101. Id.

102. See text accompanying note 62 supra.

103. See text accompanying note 76 supra. 
ness and unlawfulness of acts done in company, noted, "Every man in peaceable manner, may assemble a meet company (and inay come) . . . to remove, or cast down any common Nusans done to them."104 Presentment juries at leets and quarter sessions regularly presented common nuisances which the court ordered abated. Abatement of public nuisances upon watercourses was a regularly implemented power of the commissioners for sewers. ${ }^{105}$ The area of private-as distinct from common, or public-nuisance was highly developed, and action upon the case for nuisance explicitly lay when a house was constructed on new foundations in such manner as to stop light, air, or prospect. ${ }^{106}$

Star Chamber's acceptance of the argument that a new building raised on new foundations in London and its environs constituted a common nuisance was only a shight extension of the doctrine of nuisance from the private to the public sphere. It was enough to afford legal justification for the building's demolition. In Star Chamber's general decree against building of February 14, 1637, the court secured the "generall resolution" of all the judges of the common law courts that such building and dividing of tenements

is a most unsufferable annoyance against the Publique, and consequently is against the Common law of the Realme; And that not only the said evil conditioned Inhabitants, but such by whom, or by whose meanes they are placed there, or who receive the rents of such Inhabitants, are guiltie of a Common Nuisance . . . . 107 $^{10}$

The judges' resolution settled at common law the legal question as to whether building in violation of the proclamation was a contravention of the law. It was, and with the judges' resolution the question as to the legal effect and the legislative validity of proclamations was made moot in the matter of building.

Since Star Chamber and latterly the judges concluded that the common law of common nuisance was applicable for the purpose of grounding demolition, it follows that the common law courts, particularly leets and quarter sessions which regularly dealt with common nuisances, might have alone controlled building in the metropolis by common law. There was a suggestion made, very early in the attempt at control, that these jurisdictions should exercise their responsibilities in this matter. In the Star Chamber case of Attorney-General

104. M. Dalton, The Countrey Justice 280 (1655).

105. R. Callis, The Reading of Robert Callis on Sewers 255-69 (1685) (read in August 1622).

106. W. Sheppard, Actions upon the CASe ch. 5 (1663) (especially at 121, citing earlier authorities including Coke).

107. A Decree in Starre-Chamber: concerning Inmates and Divided Tenements (1636/37), STC 7756. 
v. Cryspe 108 (1598), Lord Keeper Egerton (afterwards Lord Ellesmere) observed: "that the Attorney [General] of the Queen is well able by common law of the realm . . . to bring a quo warranto against every privileged place, and that would be a good service to the Queen and the commonweal, for that in these places are commonly unany misdenneanors and idle persons inhabiting."100 Egerton was suggesting to the Attorney-General, Sir Edward Coke, that he might bring an information in the nature of a quo warranto in the King's Bench against the inetropolis' franchises-the city corporations of London and Westminster and the lord of leets-for non-user of their common law jurisdiction to suppress common nuisances. ${ }^{110}$ The threat of quo warranto conceivably would persuade the civic authorities to control building. While it was a brilliant device there is no evidence that Coke acted upon the suggestion. The process would have been very cumbersome had it been necessary to go beyond using it as a threat, and it would have raised a political storn in London.

Had there been a statute incorporating the provisions which were promulgated in the various proclamations against building, there would have been no questions raised with respect to legality. The great irony of the government's attempt to control London building was that a statute restricting new building in the metropolis had been enacted in 1592-1593 during Elizabeth I's reign. ${ }^{111}$ Coke was Speaker of the Commons in 1592-1593 and Attorney-General in 1601 when the Act was repealed and we nnust, for want of other evidence, take his word as to what happened to the statute:

[T]hat [statute] endured but for seven years, and until the end of the next Session of Parliament, which Act, being lolden dangerous, was not continued at the Session of Parliament holden in 43 Eliz. [1601] ... and therefore expired with the same. In the nean time there was a law made against new buildings, etc., which then was a warrant, and since hath been a colour for divers proceedings in Courts of Justice, not observing the expiration of that; but now that law hath long since lost his force, and the ancient and Fundamentall Common law is to be followed. ${ }^{112}$

108. Inner Temple Library, Petyt MS. 511, v.13, f.117; see text accompanying note 64 supra.

109. Id.

110. See 2 E. CoKE, supra note 97, at 494-99. The best recent treatment of quo warranto before the later seventeenth century use of it is the late H.E. Cam's introduction to 1 The Eyre of London A.D. 132I, 85 SeLDEN SocIETY 1xxii-1xxxvi (1968) (especially on non-user see $i d$. at lxxxiv-lxxxv).

111. 35 Eliz. 1, c. 6 (1592-93). Its restrictions on new buildings extended to three miles beyond the gates of London. The statute also restricted the conversion and dividing of dwellings and prohibited inmates.

112. 2 E. CoKE, supra note 97, at 204. The statute did not provide for demolition, only for a fine for each month the violation continued upon information (including coin- 
Coke gives no citation to the "law" which he refers to in the last sentence. It appears to have been Elizabeth's proclamation of $1602,{ }^{113}$ which, not surprisingly perhaps, nnakes no reference to the expired statute. We can only speculate why the Queen and the Privy Council in 1601 did not press parliament hard enough to assure continuance of the 1592-93 Act. It was a stormy parliament, in full cry against royal grants of monopoly, the parliament in which the aged Queen delivered her dulcet "golden speech" with enough effect to still the turbulence of the Commons. It was a parliament in which for the first time the government of Elizabetli was itself hard pressed to secure the essentials of legislation and grant of taxes. ${ }^{114} \mathrm{~A}$ statute restricting building in the inetropolis, which does not appear to have been the ground for government action anyway, was expendablc. Proclamation and the weighty sanctions of Star Chamber would suffice.

The government made one subsequent attempt to secure a statutory foundation for the control of London building. On May 21, 1621, a bill entitled "An act for the ordering and settling the manner of buildings, and for restraint of inmates and dividing of teneinents in and near the Cities of London and Westminister" was given a first reading in the Commons. ${ }^{115}$ The provisions of the bill were obviously drawn from the recent proclamations of James. ${ }^{116}$ It came at the most inauspicious moment possible. The parliament of 1621 impeached and convicted Lord Chancellor Bacon for corruption, brought down royal monopolists, and directly confronted the King and his prerogative to determine the foreign policy of the realm. Legislation that involved the exercise of wide ranging powers against substantial elements in the society-especially those powers already tainted with the prerogative in prior exercise-was virtually unobtainable. There were no further proceedings on the bill; but then, there was no legislation passed in that parliament.

Proclamation and the weighty sanctions of Star Chamber would have to suffice. Yet the days of both were numbered. Had the attempt to control building in London been based on statute it might have left a legacy in this one area of environmental control. It would have left a substantive law, the statute itself, whicli, when the turmoil of revolution was over and the necessities of dealing with con-

mon information) in the common law courts. It contained a proviso saving the "good usages or Custoins" of London, Westminster, and lords of leets in the matter of buildings, which gives some credibility to Egerton's suggestion for using quo warranto in the matter. See text accompanying note 104 supra.

113. See text accoinpanying note 43 supra.

114. J. Neale, Elizabeth I and Her Parliaments, 1584-1601 pt. 6 (1958).

115. HLRO, Main Papers, supra note 6, at (27 Apr.-12 May 1621) ff. 99-111.

116. See text accompanying note 45 supra. 
tinuing growth in the metropolis were faced again in peaceful circumstances, might have been the foundation for an effective law of urban planning from the late seventeenth century onwards. Moreover, had building control been based on statute it might have escaped the close identification with Star Chamber, or at least identification with only Star Chainber, which made so many ambitious programs of the Tudor and Stuart monarchy casualties with the monarchy itself. The opportunity was lost, perhaps as early as 1601 .

The government's program to control building in the metropolis was certainly not popular with those who felt its weight. Still, it might have been more generally popular than the government or Star Chamber. Two of the minor ironies of an era full of ironies were two petitions presented to parliament, one to the House of Lords on July 21,1641 , and the other to the House of Commons on August 16, 1641, neither of which appears to have been acted upon. ${ }^{117}$ The former was from the inhabitants of Westminster and the suburbs of London in Middlesex. It recited the proclamations, the decrees of Star Chamber, and the orders of the Privy Council against building; noted that since the abolition of Star Chamber a fortnight before some question had arisen how far the same should be executed. It prayed the Lords to order the magistrates and civic officers to "carefully performe the same" or to make other orders. The second petition, in much the same vein, complained of the mcreased building in Lincoln's Inn Fields and vicinity. It was the petition of the barristers and students of Lincoln's Inn. Prominent among the signatories was William Pyrnne, barrister, who had twice suffered in Star Chamber for sedition and blasphemy and only a few months before had been returned by parliainentary insistence from what was to have been perpetual imprisonment on sentence of Star Chamber. Building control was dead. If, though, it could count among its mourners a barrister closely identified with the revolution that destroyed it, its value was recognized.

117. HLRO, Main Papers, supra note 6, at (17-26 July 1641) f. 61, \& (14-28 Aug. 1641) f. 28. 


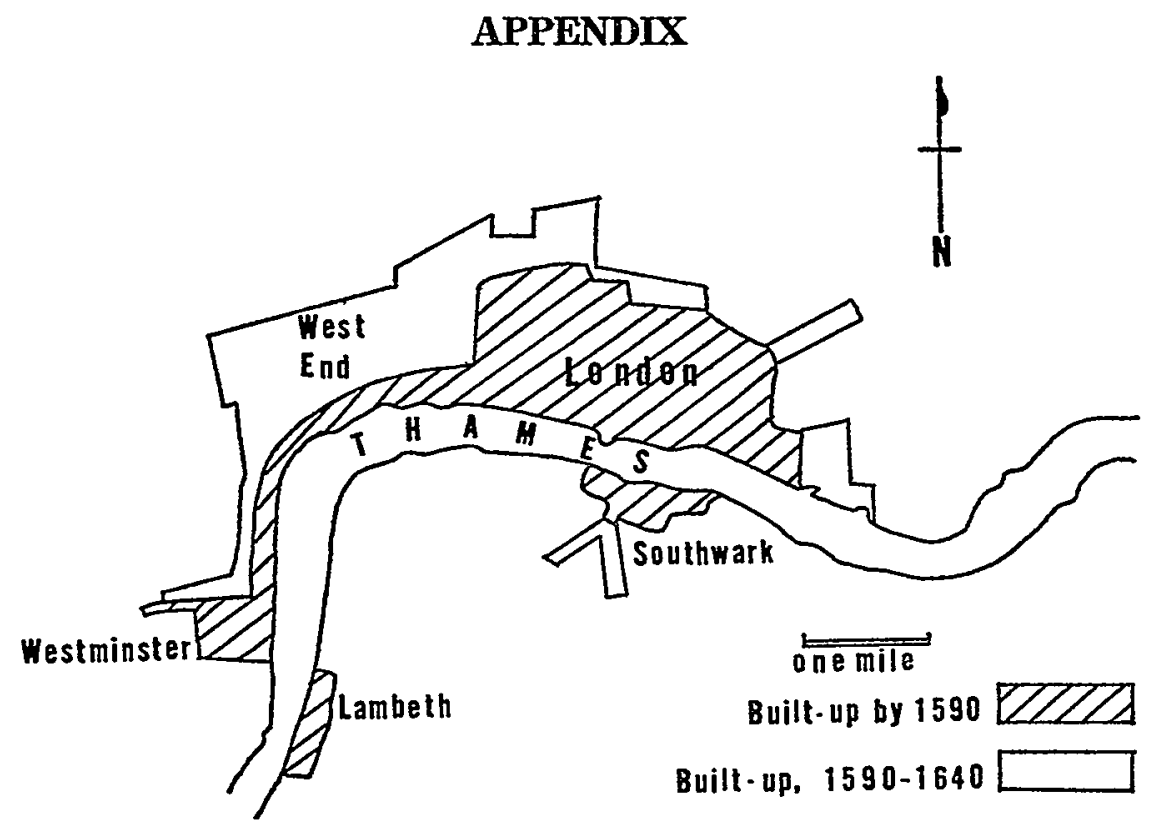

